\title{
GALOMBANG DUNIE DAN BUJANG MARANTAU: KAJIAN PROSES KREATIF PENGARANG
}

\author{
Fahmi Fahrozi ${ }^{*}$, Silvia Rosa ${ }^{2}$ Pramono $^{3}$ \\ fahroziifahmi@ymail.com* \\ Fakultas Ilmu Budaya Universitas Andalas ${ }^{1,2,3}$
}

\begin{abstract}
ABSTRAK
Artikel ini menguraikan proses kreatif penggarapan naskah randai yang bertemakan merantau antara dua orang pengarang yang berbeda domisili. Naskah randai yang dituliskan oleh Jamaluddin Umar yang berjudul Galombang Dunie dituliskan di daerah asal (kampung) Minangkabau; sedangkan naskah randai yang ditulis Namlani yang berjudul Bujang Marantau dituliskan di daerah rantau Minangkabau (Denpasar, Bali). Penelitian ini menggunakan metode penelitian sosiologi sastra. Adapun tahap-tahap dalam penelitian ini adalah tahap pengumpulan data, tahap analisis, dalam penarikan simpulan. Untuk menganalisis proses kreatif, dalam penelitian ini dilakukan analisis latar belakang sosial, proses kreatif kedua pengarang, dan faktor pendorong terjadinya proses kreatif.

Hasilnya, proses kreatif kedua pengarang dipengaruhi oleh latar belakang keluarga, latar belakang pendidikan dan latar belakang pekerjaan. Selanjutnya proses kreatif naskah randai Galombang Dunie dan naskah randai Bujang Marantau meliputi proses mendapatkan ide, proses inkubasi, proses iluminasi, proses verifikasi dan proses publikasi karya. Terakhir, faktor pendorong terjadi proses kreatif terhadap naskah randai Galombang Dunie dan naskah randai Bujang Marantau meliputi pengaruh pengalaman dalam menentukan tema dan pengaruh psikologis dalam menentukan tema dan hasil kreativitas dalam menentukan tema.
\end{abstract}

Kata kunci: Jamaluddin Umar, Namlani, Proses Kreatif, Randai.

\section{GALOMBANG DUNIE AND BUJANG MARANTAU: A STUDY OF THE AUTHOR'S CREATIVE PROCESS}

\begin{abstract}
This article describes the creative process of working on two randai scripts with the theme of migrating between two authors with different domiciles. The randai manuscript written by Jamaluddin Umar entitled Galombang Dunie was written in the origin of Minangkabau. In contrast, the randai script written by Namlani entitled Bujang Marantau was written in the Minangkabau rantau area (Denpasar, Bali). This study uses the sociology of literature research method. The stages in this research are the data collection stage, the analysis stage, in concluding. In analyzing the creative process, this research analyzes the social background, the two authors' creative process, and the creative process's driving factors.

As a result, the two authors' creative process was influenced by family background, educational background, and occupational background. Furthermore, the creative process of the Galombang Dunie randai script and the Bujang Marantau randai script includes the process of getting ideas, the incubation process, the illumination process, the verification process, and the work publication process. Finally, the driving factor for the creative process of the Galombang Dunie randai script and the Bujang Marantau randai script includes the influence of experience in determining themes and psychological influences in determining themes, and the results of creativity in determining themes.
\end{abstract}

Keywords: Jamaluddin Umar, Namlani, Creative Process, Randai

Jurnal Elektronik WACANA ETNIK - Vol 9 No 1 2020, (29-39) p ISSN 2089-8746, e ISSN 2302-7142

Submit: Februari 2020. Diterima: Maret 2020. Publikasi: April 2020. 


\section{PENGANTAR}

Seni drama merupakan salah satu cabang seni yang paling akrab dengan kehidupan masyarakat yang berarti menggambarkan tata cara dan persoalan kehidupan manusia pada zamannya (Achmad, 2006: 2). Drama tradisional yang berkembang di tengah tradisi masyarakat Minangkabau salah satunya yaitu randai. Randai menurut Achmad (2006: 119) adalah suatu bentuk teater tradisional yang bersifat kerakyatan yang terdapat di daerah Minangkabau, Sumatra Barat. Sampai saat ini, Randai masih hidup dan bahkan berkembang serta masih digemari oleh masyarakatnya, terutama di daerah perdesaan atau di kampung-kampung. Sedangkan Navis (1984: 275) mengatakan randai dibawakan banyak orang. Mereka bermain membuat lingkaran sambil melangkah kecil-kecil secara perlahan mereka bernyanyi berganti-gantian. Penelitian ini menempatkan naskah randai sebagai drama dimensi sastra, sehingga permasalahan yang muncul hanya seputar naskah, teks dan unsur cerita.

Di dalam naskah randai terdapat banyak tema yang diungkapkan oleh pengarang, salah satunya adalah tema merantau. Merantau menurut Naim (1984: 2) merantau berarti “migrasi”, tetapi “merantau” adalah tipe khusus migrasi dengan konotasi budaya tersendiri yang tidak mudah diterjemahkan ke dalam bahasa Inggris atau bahasa barat manapun. Merantau adalah istilah Melayu, Indonesia dan Minangkabau yang sama dan pemakaiannya dengan akar kata "rantau". Tetapi dari sudut pandang (Winstedt dalam Naim, 1984) rantau ialah kata benda yang berarti dataran rendah atau daerah aliran sungai. Jadi biasanya terletak dekat ke- atau bahagian dari daerah pesisir. Merantau ialah kata kerja yang berawalan "me-“ yang berarti "pergi ke rantau”. Tetapi dari sudut sosiologi, istilah ini sedikitnya mengandung enam unsur pokok. Keenam unsur itu adalah meninggalkan kampung halaman dengan kemauan sendiri untuk jangka waktu yang lama atau tidak. Tujuannya untuk mencari penghidupan, menuntut ilmu atau mencari pengalaman, biasanya dengan maksud kembali pulang. Merantau ialah lembaga sosial yang membudaya.

Naskah randai yang bertemakan merantau menjadi salah satu objek yang menarik untuk dikaji dalam studi sastra. Tema merantau menjadi inspirasi banyak karya sastra, salah satunya naskah randai. Tema tentang merantau memiliki permasalahan yang cukup rumit dan sangat menarik untuk dikaji. Terutama ketika tema-tema tersebut digarap dan diolah oleh pengarang yang sekaligus sebagai perantau Minangkabau. Pengarang yang langsung merasakan kejadian sosial di daerah rantau memiliki pandangan sendiri terhadap naskah randai yang bertemakan merantau. Berbeda dengan pengarang yang menuliskan naskah randai bertema merantau yang berdomisili di daerah asalnya. Dari dua pengarang yang menuliskan naskah randai tersebut yaitu Jamaluddin Umar dan Namlani. Jamaluddin Umar menuliskan naskah randai yang berjudul Galombang Dunie. Naskah randai Galombang Dunie yang bertema merantau ini terdapat dalam buku "Naskah Randai Pilihan".

Buku “Naskah Randai Pilihan” dikarang oleh Jamaluddin Umar dan Musra Dahrizal. Di dalam buku tersebut terdapat empat buah naskah randai yaitu Sabai Nan Aluih, Lareh Simawang Jo Diri Siti Jamilah, Maelo Rambuik Dalam Tapuang dan Galombang Dunie. Dua dari naskah randai ditulis oleh Jamaluddin Umar yang berjudul Maelo Rambuik Dalam Tapuang dan Galombang Dunie. Dua naskah randai lainnya ditulis oleh Musra Dahrizal yaitu Sabai Nan Aluih dan Lareh Simawang Jo Diri Siti Jamilah. Naskah randai Galombang Dunie merupakan satu-satunya pada buku tersebut yang bertema merantau, selebihnya memiliki tema yang berbeda. Naskah randai Sabai Nan Aluih

Jurnal Elektronik WACANA ETNIK - Vol 9 No 1 2020, (29-39) p ISSN 2089-8746, e ISSN 2302-7142 
bertema tentang perjuangan perempuan, naskah randai Lareh Simawang Jo Diri Siti Jamilah bertema konflik percintaan dan naskah randai Maelo Rambuik Dalam Tapuang bertema permasalahan keluarga. Lain halnya dengan Namlani yang menuliskan naskah randai Bujang Marantau, naskah randai Bujang Marantau ditulisnya di daerah perantauan dan belum diterbitkan.

Problematika dalam proses merantau di kedua naskah randai ini merupakan persoalan yang menarik untuk diteliti melalui sosiologi sastra khususnya sosiologi pengarang. Menurut Wellek \& Warren dalam Damono (2002: 3) menyatakan sosiologi pengarang yaitu memasalahkan status sosial, ideologi sosial, dan lain-lain. Menyangkut pengarang sebagai penghasil sastra pada banyak penelitian terdahulu. Pengarang bisa diperlakukan sebagai individu maupun sebagai suatu sistem. Masing-masing pengarang memiliki proses kreatifnya yang berbeda-beda. Dengan demikian, karya sastra hadir sebagai gambaran sosial masyarakat yang telah mengalami proses kreatif dan imajinasi dari pengarang.

\section{KERANGKA TEORI DAN METODE}

Sosiologi sastra menurut Damono (2002: 10) merupakan telaah yang objektif dan ilmiah tentang manusia dalam masyarakat, telaah tentang lembaga dan proses sosial. Sastra berurusan dengan manusia di dalam masyarakat, usaha manusia untuk menyesuaikan diri dan bagaimana usahanya untuk mengubah masyarakat tersebut.

Menurut Wellek dan Werren sosiologi sastra terbagi atas tiga cakupan yaitu a) Sosiologi Karya; b) Sosiologi Pembaca; dan Sosiologi Pengarang (Damono, 2002: 3-4). Sosiologi karya yaitu yang memasalahkan karya sastra itu sendiri yang menjadi pokok penelaahan adalah apa yang tersirat dalam karya sastra dan apa yang menjadi tujuannya. Dalam hal ini kita bisa memusatkan perhatian pada sebuah atau beberapa buah novel yang ditulis oleh seorang atau lebih pengarang untuk kemudian mengajukan pertanyaan mengenai tujuan penulisannya seperti yang tersurat di dalam karya-karya itu dalam kaitannya dengan lingkungan sosial budaya yang telah menghasilkannya. Sosiologi pembaca yaitu yang memasalahkan pembaca dan pengaruh sosial karya sastra yang dibaca. Pembaca karya sastra berasal dari bermacam-macam golongan, kelompok, agama, pendidikan, umur dan sebagainya. Pertanyaan penelitian bisa diajukan terhadap pengaruh karya sastra itu terhadap sekelompok pembaca, jika pengaruh itu dianggap buruk oleh masyarakat umum atau pemerintah, misalnya, bisa saja karya sastra itu dilarang beredar. Sosiologi pengarang yaitu yang memasalahkan status sosial, ideologi sosial dan lain-lain yang menyangkut pengarang sebagai penghasil sastra. Dalam banyak penelitian, pengarang bisa diperlakukan sebagai individu maupun sebagai suatu sistem. Hal demikian dapat menekankan penelitian kepada sistem pengarang yang ada di Indonesia dengan memasalahkan kelompok umur, tingkat pendidikan, kecenderungan ideologi, agama dan lain-lain (Damono, 2002: 3-4).

Menurut Farris (dalam Siswanto, 2008: 25) proses yang dilalui secara umum oleh penulis (sastrawan) bisa dikelompokkan atas kegiatan pramenulis, penulisan, penulisan kembali dan publikasi. Tahapan yang lebih rinci dikemukakan Tompkins atau Donald Graves (dalam Siswanto, 2008: 25) yaitu pramenulis, penulisan draft, revisi, penyempurnaan, dan publikasi. Dalam kata lain proses kreatif dapat dikelompokkan menjadi tiga kegiatan pramenulis, saaat menulis dan paska menulis. 
Endraswara membagi tahapan proses kreatif meliputi empat tahap yaitu 1) Tahap Persiapan. Tahap pengumpulan informasi dan data yang dibutuhkan, pengalaman-pengalaman yang mempersiapkan seseorang untuk melakukan tugas dan memecahkan masalah tertentu. 2) Tahap inkubasi. Pada tahap ini pengarang untuk sementara waktu mengendapkan semua ide dan pengalamannya. Hal ini berlangsung beberapa saat, beberapa hari, bahkan bisa bertahun-tahun. Pengarang tidak bisa menentukan saatnya. Tergantung kesiapan si pengarang itu sendiri. 3) Tahap iluminasi. Pada tahap ini pengarang telah bisa untuk menuangkan segala ide, gagasan dan pengalamannya dalam bentuk tulisan. Sampai akhirnya tulisan itu siap. Pada tahap ini pengarang merasakan kebahagiaan karena apa yang tadinya masih berupa gagasan-gagasan sekarang sudah menjadi nyata. 4) Tahap verifikasi. Tahap di mana sebuah tulisan yang telah dihasilkan tadi dinilai oleh pengarang sendiri. Pada tahapan ini pengarang menjadi seorang yang kritis. Ia melihat tulisannya dari sudut pandang orang lain. Apakah tulisan itu perlu dimodifikasi, direvisi, ditambah, atau dihilangkan bagian-bagian tertentu supaya karya tersebut sudah bisa disebut 'jadi' dan siap untuk dipublikasikan (Endaswara, 2008: 222-223). Sementara Siswanto (2008: 25) membagi empat tahap proses kreatif yang dilalui oleh pengarang. Empat proses kreatif itu adalah alasan dan dorongan menjadi pengarang. Kegiatan sebelum menulis, kegiatan selama menulis dan kegiatan setelah menulis.

Objek penelitian ini adalah naskah randai Galombang Dunie karya Jamaluddin Umar dan naskah randai Bujang Marantau karya Namlani beserta hasil dari wawancara kedua pengarang tersebut. Naskah randai Galombang Dunie diambil dari buku Naskah Randai Pilihan karya Musra Dahrizal Katik Jo Mangkuto dan Jamaluddin Umar, dan naskah randai Bujang Marantau karya Namlani diperoleh dalam bentuk ketikan, belum diterbitkan. Adapun metode yang digunakan dalam penelitian ini adalah metode penelitian sosiologi sastra.

Tahapan awalnya adalah mengumpulkan data yang terkandung di dalam naskah randai Galombang Dunie karya Jamaluddin Umar dan naskah randai Bujang Marantau karya Namlani. Tahap selanjutnya yaitu menggunakan metode wawancara kepada pengarang terkait latar belakang sosial dan proses kreatif pembentukan naskah randai Galombang Dunie dan naskah randai Bujang Marantau serta mencari tahu faktor apa saja yang menjadi penyebab proses kreatif oleh kedua pengarang tersebut.

Analisis data dilakukan dengan menggunakan teori sosiologi sastra, khususnya sosiologi pengarang. Hasil wawancara turut dipakai sebagai data yang akan dianalisis. Analisis ini dilakukan untuk menemukan proses kreatif pengarang dan faktor apa saja yang menjadi penyebab kreativitas pengarang serta mengetahui latar belakang sosial pengarang dalam menuliskan naskah randai bertemakan merantau.

\section{HASIL DAN PEMBAHASAN}

Proses kreativitas yang dialami oleh pengarang tidak terlepas dari faktor-faktor penyebab yang dilaluinya. Masing-masing pengarang memiliki pengalaman dan kejadian yang berbeda-beda. Proses yang dilalui oleh pengarang dalam menuliskan naskah randai melalui langkah-langkah seperti pra penulisan, penulisan, penulisan ulang hingga sampailah pada tahap publikasi karya. Berdasarkan tahapan-tahapan tersebut, tentu memiliki faktor-faktor pendorong terjadinya proses dalam berkreativitas. 


\section{Faktor Kreativitas Jamaluddin Umar}

Di dalam penggarapan atau pembuatan naskah randai, memiliki banyak faktor-faktor yang menjadi pemicu timbulnya kreativitas tersebut. Hal ini dikarenakan masing-masing pengarang memiliki ide atau gagasan yang berbeda-beda. Pengalaman pribadi pengarang juga menjadi salah satu faktor penyebabnya. Kadang pengarang melihat atau mendapatkan ide dari pengalaman orang lain. Maka dari itu kreativitas sangat erat kaitannya dengan proses penulisan karya sastra oleh pengarang.

Jamaluddin Umar memulai penulisan naskah randai dengan melihat pertunjukan seni tradisi randai dan kemudian mulai membaca-baca naskah randai yang lainnya. Jamaluddin Umar banyak membaca naskah randai yang bercirikan kiasan-kiasan khas Minangkabau dan menjadikan hal tersebut referensi penulisan naskah randainya. Hal tersebut harus dihadirkan di dalam naskah randai karena menurut Jamaluddin Umar inti dari penampilan pertunjukan randai terletak di bagian kesusastraannya.

Ciri-ciri kreativitas naskah randai Galombang Dunie yang dibuat oleh Jamaluddin Umar tidak akan terlepas dari pengaruh pengalaman atau pengaruh psikologis Jamaluddin Umar dalam menentukan tema. Pada hal ini, Jamaluddin Umar memilih tema merantau dalam naskah randai Galombang Dunie. Jamaluddin Umar sebetulnya belum pernah merantau, namun dengan melihat keadaan masyarakat sepulang merantau dan beberapa pandangan dari orang terhadap merantau, Jamaluddin Umar akhirnya dapat referensi untuk mengembangkan kreativitas terhadap naskah randai yang bertemakan merantau.

\section{Pengaruh Pengalaman dalam Menentukan Tema}

Pengalaman merupakan suatu kejadian atau peristiwa yang dialami seseorang dan berpengaruh terhadap kehidupannya sekarang ini. Pengalaman pengarang dalam membuat naskah randai menjadi salah satu faktornya. Pengarang banyak membuat karya sastranya berdasarkan kejadian yang dialaminya di masa lalu. Sehingga apa yang langsung dirasakannya bisa melekat dalam karyanya. Ada juga pengarang yang membuat karya sastra berdasarkan melihat atau mengamati dari pengalaman orang lain. Bagaimana tingkah laku seseorang terhadap merantau kemudian dituangkan ke dalam sebuah naskah randai dan tidak kalah bagus dari pengarang yang merasakannya sendiri.

Jamaluddin Umar termasuk ke dalam pengarang yang melihat dan mengamati pengalaman dari orang lain kemudian dijadikan sebuah naskah randai. Apa yang menjadi penyebab masyarakat merantau, bagaimana kehidupan di daerah rantau, itulah yang menjadi ide-ide yang muncul dalam kepala Jamaluddin Umar dalam membuat naskah randai berdasarkan pengalaman orang lain. Jamaluddin Umar enggan untuk merantau, menurutnya orang yang pergi merantau lebih banyak merugi dibandingkan untungnya. Lebih baik di kampung menjaga harta warisan dan mengembangkannya.

Jamaluddin Umar juga merupakan orang yang sering bertukar pikiran dengan orang lain. Menggeluti dunia seni tradisi Minangkabau sedari kecil hingga sekarang sudah membuat sebuah sanggar yang bernama "Palito Nyalo" dan sudah berdiri selama kurang lebih 32 Tahun. Karena hal itulah Jamaluddin Umar sering bepergian ke sasaran atau sanggar lainnya untuk mempelajari seni tradisi atau bersilaturahmi sehingga mendapatkan berita-berita mengenai kehidupan orang merantau dan mengaplikasikannya ke naskah randai Galombang Dunie.

Jurnal Elektronik WACANA ETNIK - Vol 9 No 1 2020, (29 - 39) p ISSN 2089-8746, e ISSN 2302-7142 
Adanya sebuah wadah untuk menyalurkan ide-ide kreatif menjadi penyemangat Jamaluddin Umar terus membuat naskah randai, salah satunya naskah randai Galombang Dunie. Berdasarkan visi dari Sanggar Seni "Palito Nyalo" yang sudah berdiri selama 32 tahun, yaitu menggali, menumbuhkan, mengembangkan dan melestarikan kebudayaan Minangkabau, maka hal inilah yang menjadikan Jamaluddin Umar untuk terus giat berkarya. Walaupun tidak merasakan langsung bagaimana rasanya itu merantau, namun Jamaluddin Umar sanggup untuk menghadirkan tema merantau di dalam naskah Galombang Dunie karangan pertamanya.

\section{Pengaruh Psikologis dalam Menentukan Tema}

Pengaruh psikologis kepada pengarang terhadap menentukan tema naskah randai sangatlah besar dampaknya. Kondisi psikologis menjadikan pengarang ingin atau tidaknya dalam membuat karya sastra. Psikologi tidak hanya mempelajari jiwa ataupun mental saja, namun juga mencakup berbagai aspek di luar kejiwaan. Ekspresi dari jiwa/mental pengarang akan menghasilkan suatu karya sastra. Maka dari itu psikologi sangat besar dampaknya terhadap pengarang dalam membangun naskah randai dan juga temanya.

Setiap masing-masing pengarang memiliki kondisi psikologis yang berbeda. Bagaimana latar belakang kondisi mental atau kejiwaannya menjadi penentu dalam menentukan Tema. Dalam hal ini kejadian-kejadian di masa lalu bisa menjadi pemicu pengarang tersebut terinspirasi untuk membuat tema yang terpikirkan olehnya. Maka dari itu faktor-faktor psikologis tidak bisa dikesampingkan dalam hal-hal semacam ini.

Jamaluddin Umar tergolong orang yang enggan untuk pergi merantau. Namun berdasarkan hasil pengamatan dari fenomena-fenomena yang terjadi di lingkungan sekitarnya, Jamaluddin Umar bisa menghadirkan tema merantau dalam naskah randainya. Hal itu tidak terlepas dari faktor psikologis yang pernah dilalui semasa sebelum melakukan penggarapan tema merantau.

Berdasarkan kejadian yang pernah dialami oleh Jamaluddin Umar, menimbulkan pengaruh psikologi bagi kondisi mentalnya untuk tidak berkeinginan pergi merantau dikala itu. Namun, karena hal itulah yang menjadi pemicu Jamaluddin Umar untuk menetap di kampung dan berkarya sehingga terbentuklah naskah randai yang bertemakan merantau berjudul Galombang Dunie.

Pengaruh psikologis lainnya yang menjadi penyebab terbentuknya tema merantau dalam naskah randai Galombang Dunie yaitu adanya tekanan dari lingkungan sekitar yang membuat stigma kalau anak laki-laki Minangkabau harus mencoba pergi merantau terlebih dahulu. Teman sebaya Jamaluddin Umar pada saat itu sudah banyak yang pergi merantau, namun Jamaluddin Umar lebih memilih jalan untuk tetap berada di kampung halaman dan mengolah harta warisan yang ada.

\section{Hasil Kreativitas dalam Menentukan Tema}

Setelah terbentuknya ide-ide dan gagasan yang tertuangkan dalam sebuah karya sastra, pengarang akan menghasilkan suatu karya sastra yang diinginkannya. Karya sastra tersebut telah melalui proses kreativitas yang panjang sehingga terbentuklah garapan-garapan yang dikehendaki oleh pengarang. Sehingga karya sastra yang kita nikmati saat sekarang ini layak untuk diapresiasi keberadaannya. 
Naskah randai Jamaluddin Umar telah banyak melalui proses kreativitasnya. Dengan menentukan tema merantau ke dalam naskah randai Galombang Dunie, Jamaluddin Umar tidak harus merasakan bagaimana rasanya merantau itu sendiri. Jamaluddin Umar akan mencari sumber-sumber inspirasi melalui fenomena-fenomena yang dia lihat di lingkungan sekitarnya. Serta juga mendapatkan masukan dari rekan-rekan yang telah merantau sebelumnya dan terbentuklah naskah randai Galombang Dunie yang bertemakan merantau.

Bentuk-bentuk kreativitas yang ditanamkan ke dalam naskah randai oleh Jamaluddin Umar sangatlah terasa apabila langsung mencermati isi karya sastranya. Bait-bait yang padat akan makna dan kiasan-kiasan indah keminangkabauan masuk semuanya di dalam naskah randai Galombang Dunie.

Mulai dari pantun, dendang Pauh dan pantun-pantun dalam rabab menjadikan Jamaluddin Umar termotivasi untuk membuat naskah randai yang padat akan makna. Naskah randai Galambang Dunie pun hadir dengan menceritakan kehidupan di daerah rantau dan ceritanya sesuai dengan apa yang diminati oleh masyarakat Minangkabau di kampung.

Semua yang dilakukan oleh Jamaluddin Umar tidak terlepas dari motivasi awalnya dalam penggarapan naskah randai. Jamaluddin Umar memiliki motivasi untuk mempertahankan budaya Minangkabau yang ada di lingkungan sekitar melalui naskah randai yang kemudian dimainkan dalam sebuah acara pertunjukan randai. Kampung halaman Jamaluddin Umar dekat dengan salah satu Universitas, timbullah ketakutan dalam dirinya apabila tidak terus mengembangkan budaya Minangkabau, takutnya akan tergeser oleh kebudayaan orang luar yang dibawanya dari kampung halaman masing-masing. Bertolak dari sanalah timbul faktor-faktor kreativitas Jamaluddin Umar untuk terus berkarya dalam kesenian Minangkabau, terkhususnya pada naskah randai.

Naskah randai merupakan salah satu media untuk melakukan hal tersebut. Banyaknya pendatang dari daerahdaerah luar menjadi kekhawatiran bagi Jamaluddin Umar karena takut akan tergerusnya budaya setempat. Apabila sudah melakukan tradisi-tradisi kebudayaan yang telah diwariskan oleh leluhur, maka minimal para pendatang tersebut akan segan untuk membuat hal yang tidak diinginkan di wilayah mereka.

\section{Faktor Kreativitas Namlani}

Penggarapan atau pembuatan naskah randai, memiliki banyak faktor-faktor yang menjadi pemicu timbulnya kreativitas tersebut. Hal ini dikarenakan masing-masing pengarang memiliki ide atau gagasan yang berbeda-beda. Pengalaman pribadi pengarang juga menjadi salah satu faktor penyebabnya, bisa juga pengarang melihat atau mendapatkan ide dari pengalaman orang lain, maka dari itu kreativitas sangat erat kaitannya dengan proses pengarang melakukan penulisan karya sastra.

Namlani pada awalnya ingin menuliskan naskah randai karena adanya kebutuhan dari organisasinya. Berbekal pengalaman berkesenian semasa di perkuliahan, mendapatkan banyak referensi dari naskah-naskah randai terdahulu dan dari cerita-cerita orang yang satu organisasi perantauan dengannya. Namlani mulai mencoba membuat naskah randai. Naskah randai Bujang Marantau yang bertemakan merantau ini, dikemas oleh Namlani dengan bahasa yang lebih ringan tanpa banyak menghadirkan bahasa kiasan-kiasan Minangkabau. 
Ciri-ciri kreativitas naskah randai Bujang Marantau yang dibuat oleh Namlani tidak akan terlepas dari pengaruh pengalaman atau pengaruh psikologis Namlani dalam menentukan tema. Namlani memilih tema merantau dalam naskah randai Bujang Marantau. Namlani merasakan bagaimana rasanya hidup di daerah perantauan dan juga melihat keadaan masyarakat perantauan di sana. Berangkat dari sanalah Namlani akhirnya dapat acuan untuk mengembangkan kreativitas terhadap naskah randai Bujang Marantau yang bertemakan merantau.

1. Pengaruh Pengalaman dalam Menentukan Tema

Pengalaman merupakan suatu kejadian atau peristiwa yang dialami seseorang dan berpengaruh terhadap kehidupannya sekarang ini. Pengalaman pengarang dalam membuat naskah randai menjadi salah satu faktornya. Pengarang banyak membuat karya sastranya berdasarkan kejadian yang dialaminya di masa lalu. Sehingga apa yang langsung dirasakannya bisa melekat dalam karyanya. Hal ini merupakan dua hal yang sangat berkaitan. Antara merantau yang dia alami prosesnya sendiri dengan merantau menjadi sumber inspirasi dalam membuat naskah randai.

Namlani merupakan pengarang yang membuat karyanya di daerah perantauan. Semua fenomena-fenomena yang terjadi di rantau telah dilaluinya. Berangkat dari hal tersebut, timbul inspirasi untuk dijadikan sebuah naskah randai. Bagaimana kehidupan di daerah perantauan, apakah daerah rantau memiliki jaminan untuk bisa bertahan hidup. Itulah yang menjadi ide-ide yang muncul dalam kepala Namlani untuk membuat naskah randai berdasarkan pengalaman yang dirasakannya sendiri. Serta pengalaman rekan-rekannya di tanah perantauan.

Namlani mendapatkan ide-ide dalam penulisan naskah randai dengan merasakan langsung bagaimana rasanya merantau itu dan juga melihat fenomena sekitar kelompoknya di daerah perantauan. Bagaimana keadaan masyarakat yang tinggal lebih lama di rantau, apa saja kendalanya dalam perjalanan merantau dan apa kejadian yang terjadi di daerah rantau. Hal itu dicurahkan ke dalam naskah randai dan menjadikan tema merantau sebagai daya tariknya.

Namlani juga merupakan orang yang aktif dalam kegiatan berkesenian Minangkabau di daerah perantauan. Namlani aktif di bidang seni dan budaya IKMS di daerah Denpasar, Bali. Setelah selesai berkegiatan seni di IKMS (Ikatan Keluarga Minangkabau Saiyo), Namlani juga sering bertukar pendapat mengenai bagaimana kondisi orangorang Minangkabau di Bali ini. Banyaknya masukan dan cerita dari orang-orang yang lebih tua, menjadikan pengalaman tersebut suatu sumber kreativitas yang didapatkan oleh Namlani dalam membuat naskah randai bertemakan merantau. Selain itu Namlani sendiri pun juga bisa menjadi tolak ukur bagaimana kondisinya di daerah perantauan karena dia juga merupakan seorang perantau Minang dan bisa juga dimasukkan pengalamannya ke dalam naskah randai.

Kreativitas yang dihadirkan oleh Namlani yaitu membuat naskah randai yang terkesan lebih ringan tanpa adanya dialog-dialog kiasan Minangkabau yang khas dalam naskah randai. Ini disebabkan karena masyarakat perantauan di sana lebih mudah mencerna bahasa Minangkabau yang umum jika dibandingkan dengan bahasa kiasankiasan yang padat akan makna.

2. Pengaruh Psikologis dalam Menentukan Tema

Jurnal Elektronik WACANA ETNIK - Vol 9 No 1 2020, (29 - 39) p ISSN 2089-8746, e ISSN 2302-7142 
Pengaruh psikologis berpengaruh besar terhadap pengarang menentukan tema. Ini dikarenakan dalam penulisan naskah randai menyertakan emosi dan mental dalam proses kreatifnya. Terlebih lagi keadaan psikologi pengarang yang berbeda-beda semenjak ia dilahirkan. Apabila tidak memasukkan perasaan ke dalam naskah randai, maka karya tersebut akan terasa kurang menarik untuk dinikmati.

Masing-masing pengarang memiliki kondisi psikologis yang berbeda. Bagaimana latar belakang kondisi mental atau kejiwaannya menjadi penentu dalam menentukan Tema. Dalam hal ini kejadian-kejadian di masa lalu bisa menjadi pemicu pengarang tersebut terinspirasi untuk membuat tema yang terpikirkan olehnya. Maka dari itu faktorfaktor psikologis tidak bisa dikesampingkan dalam hal-hal semacam ini.

Namlani tergolong orang yang berani dalam melakukan tindakan. Tindakan yang dia ambil yakni mengadu nasib di daerah perantauan. Kurang lebih sudah 21 tahun Namlani merantau di daerah Bali. Berdasarkan hal itulah Namlani merasakan bagaimana rasanya liku-liku di daerah perantauan sehingga mampu untuk menghadirkan naskah randai yang bertemakan merantau. Hal ini tidak terlepas dari faktor psikologinya yang merasa tertantang untuk melakukan garapan penulisan naskah randai Bujang Marantau.

Berdasarkan hal inilah Namlani merasakan jiwanya ditantang untuk melakukan penulisan naskah randai. Masyarakat di sini ataupun masyarakat Minangkabau perantauan pada khususnya tidak mengerti apa yang terkandung dalam dialog-dialog yang dilafalkan oleh tokoh randai, maka dari itu Namlani ingin membuat naskah randai dengan simpel dan mudah dicerna di hati masyarakat luas. Namun tidak melupakan unsur keminangkabauan yang lainnya seperti latar tempat dan penggunaan bahasa Minangkabau yang tidak rumit untuk didengar. Daya semangat inilah yang menjadi salah satu faktor psikologis Namlani dalam menentukan tema merantau.

Pengaruh psikologis lainnya yang menjadi penyebab terbentuknya tema merantau dalam naskah randai Bujang Marantau yaitu adanya rasa tanggung jawab yang begitu amat besar dalam dirinya untuk harus membuat naskah Bujang Marantau. Namlani merupakan lulusan sekolah seni, bergelar S.Sn yang membuat jiwa merasa terpanggil dalam melakukan penggarapan ini. Walaupun naskah randai Bujang Marantau bersifat insidental. Akan tetapi Namlani memiliki totalitas dalam penulisan naskah randainya.

\section{Hasil kreativitas dalam Menentukan Tema}

Setelah terbentuknya ide-ide dan gagasan yang dituangkan dalam sebuah karya sastra. Maka pengarang akan menghasilkan suatu karya sastra yang diinginkannya. Karya sastra tersebut telah melalui proses kreativitas yang panjang sehingga terbentuklah garapan-garapan yang dikehendaki oleh pengarang, Lalu karya sastra yang kita nikmati sekarang ini layak untuk diapresiasi keberadaannya.

Naskah randai Namlani telah banyak melalui proses kreativitas. Namlani merasakan bagaimana rasanya merantau itu sendiri. Sehingga terinspirasi mengambil tema merantau ke dalam naskah randai Bujang Marantau. Namlani menggambarkan bagaimana keadaan masyarakat Minangkabau yang pergi merantau melalui naskah randainya. Namlani juga mendapatkan masukan dari rekan-rekan yang ada di IKMS sebelumnya. Ia juga melakukan diskusi dengan orang yang lebih tua di IKMS sehingga terbentuklah naskah randai Bujang Marantau yang bertemakan merantau. 
Bentuk-bentuk kreativitas yang ditanamkan ke dalam naskah randai oleh Namlani sangatlah mencolok jika dibandingkan dengan naskah randai yang ada pada umumnya. Jika naskah randai pada umumnya menggunakan katakata padat akan makna dan juga menggunakan kiasan-kiasan dalam bercerita, Namlani membuat dialog-dialog antara tokohnya terlihat sangat simpel. Ini bukan tanpa sebab Namlani melakukan hal tersebut agar naskah randai yang dimainkan di daerah perantauan nantinya dapat dengan mudah dicerna oleh masyarakat luas. Karena banyak dari masyarakat di sini yang kurang memahami pepatah petitih serta kiasan-kiasan khas Minangkabau dalam naskah randai pada umumnya. Namlani pintar membaca situasi kemasyarakatan yang terjadi di daerah perantauan dan kemudian dikreativitaskan menjadi naskah randai yang lebih menarik.

Berdasarkan keinginan yang kuat Namlani mampu untuk memberikan cerita tentang merantau pada naskah randainya. Berkat kegigihannya belajar menentukan pola-pola naskah randai akhirnya hadir cerita Bujang Merantau. Naskah Bujang Marantau itu sendiri tidak sanggup digarap oleh Namlani seorang diri. Namlani banyak mendapatkan masukan-masukan dari rekan-rekan di bidang seni budaya dan juga orang yang lebih tua di komunitas IKMS yang bersedia untuk membantunya. Setelah itu barulah Namlani melakukan penulisannya seorang diri. Proses kreativitas seperti inilah yang menghasilkan naskah randai Bujang Marantau yang bertemakan tentang merantau.

\section{PENUTUP}

Proses kreativitas yang dialami oleh pengarang tidak terlepas dari faktor-faktor penyebab yang dilaluinya. Masing-masing pengarang memiliki pengalaman dan kejadian yang berbeda-beda. Proses yang dilalui oleh pengarang dalam menuliskan naskah randai melalui langkah-langkah seperti prapenulisan, penulisan, penulisan ulang hingga sampailah pada tahap publikasi karya. Berdasarkan tahapan-tahapan tersebut, tentu memiliki faktor-faktor pendorong terjadinya proses dalam berkreatifitas.

Kedua naskah ini memiliki kesamaan tema yaitu tema merantau. Selain itu, kedua pengarang memperlihatkan proses kreatifitas yang berbeda dalam menuliskan naskah randai. Latar belakang sosial menjadi penyebab terjadinya perbedaan. Namun hal itulah yang menjadikan variasi tema merantau dalam naskah randai menjadi lebih menarik. Pengarang yang merasakan langsung bagaimana rasanya merantau dengan pengarang yang hanya mengamati bagaimana fenomena yang terjadi terhadap orang yang merantau tanpa merasakan bagaimana merantau itu. Ini memberikan pandangan yang berbeda dalam penentuan alur cerita merantau yang ada di dalam naskah randai. Hal inilah yang sangat kontras sekali perbedaannya antara naskah randai Galombang Dunie karya Jamaluddin Umar dan naskah randai Bujang Marantau karya Namlani.

Gaya penulisan naskah randai antara kedua pengarang juga berbeda. Jamaluddin Umar membuat dialogdialog yang efektif dan padat makna dalam naskah randai dengan menggunakan bentuk kalimat berkias yang khas dalam bahasa Minangkabau. Gaya seperti ini digunakan oleh Jamaluddin Umar disebabkan karena kecenderungan masyarakat Minangkabau yang suka mendengarkan kiasan-kiasan dalam pertunjukan randai. Namun, pada naskah randai karangan Namlani dialog antara tokohnya tidak terlalu banyak kata-kata kiasan. Ini dikarenakan faktor peminat dari naskah randai. Juga pertunjukan randai di daerah rantau, kurang diminati akan hal tersebut. Maka dari itu Namlani memberikan model yang berbeda.

Jurnal Elektronik WACANA ETNIK - Vol 9 No 1 2020, (29-39) p ISSN 2089-8746, e ISSN 2302-7142 
Perwujudan kedua naskah randai erat kaitannya dengan proses kreatif yang dilalui oleh kedua pengarang. Adapun proses kreatif yang mempengaruhi kedua pengarang dalam mengolah tema merantau ke dalam naskah randainya adalah berupa 1) proses mendapatkan ide, (2) proses perenungan, (3) proses iluminasi, (4) proses verifikasi, (5) proses publikasi. Pengarang yang berdomisili tidak di daerah rantau cenderung menggunakan gaya bahasa berkias dalam menyampaikan tema merantau. Sementara pengarang yang berdomisili di daerah rantau cenderung menggunakan kalimat bahasa Minangkabau yang sederhana, mudah dimengerti, dan tanpa kiasan.

\section{REFERENSI}

Achmad, A.Kasim. (2006). Mengenal Teater Tradisional di Indonesia. Jakarta: Dewan Kesenian Jakarta.

Bagiya, Putut Hasanudin. (2015). "Kajian Sosiologi Sastra Memang Jodoh Karya Marah Rusli dan Pembelajarannya di SMA". Jurnal Surya Bahtera. Vol.3, No.23.(http://ejournal.umpwr.ac.id/index.php/suryabahtera/article/view/4854)

Dahrizal, Musra \& Umar, Jamaluddin. (2015). Naskah Randai Pilihan. Padang: SURI (Surau Institute for Conservation).

Damono, Sapardi Djoko. (2002). Pedoman Penelitian Sosiologi Sastra. Jakarta: Pusat Bahasa.

Endaswara, Suwardi. (2008) Metodologi Penelitian Sastra: Epistemologi Model, Teori, dan Aplikasi. Yogyakarta: Pustaka Widyatama.

Fernando, Victhor. (2018). "Pandangan Dunia Pengarang Dalam Novel Mellow Yellow Drama Karya Adrey Yu Ji Hui: Kajian Strukturalisme Genetik". Jurnal Ilmu Budaya. e-ISSN 2549-7715. Vol.2, No.1:71-80. (http://ejournals.unmul.ac.id/index.php/JBSSB/article/view/1015)

Lestari, Miuru Legi. (2017). "Hubungan Aspek Sosiologi Pengarang Dengan Unsur Intrinsik dalam Novel Nijuushi No Hitomi". Jurnal Program Studi Sastra Jepang. E-ISSN 2301-5527. Vol.6, No.2. (https://scholar.google.co.id/scholar?hl=en\&as_sdt=0\%2C5\&q=Hubungan+Aspek+Sosiologi+Pengarang + De ngan+Unsur+Intrinsik+dalam+Novel+Nijuushi+No+Hitomi\&btnG=)

Naim, Mochtar. (1984). Merantau. Yogyakarta: Gadjah Mada University Press.

Navis, A.A. (1984). Alam Takambang Jadi Guru:Adat dan Kebudayaan. Jakarta: Graffiti Pers.

Ratna, Nyoman Kutha. (2007). Sastra dan Cultural Studies : Representasi Fiksi dan Fakta. Yogyakarta: Pustaka Pelajar. Siswanto, Wahyudi. (2008). Pengantar Teori Sastra. Jakarta: Garsindo.

Sumardjo, Jacob \& K.M, Saini. (1986). Apresiasi Kesusastraan. Jakarta: PT Gramedia.

Yendrisyah, Ricki. (2012). "Mamak Dalam Naskah Randai "Sumarak Nagari” Karya Buchari RM: Tinjauan Sosiologi Sastra". Skripsi. Padang: Universitas Andalas. 